\title{
Preface: Professor Dr. Hans Kerp - a birthday tribute
}

\author{
Henk Visscher ${ }^{1}$. Johanna H. A. van Konijnenburg-van Cittert ${ }^{1}$
}

Published online: 10 September 2019

(c) Paläontologische Gesellschaft 2019

\begin{abstract}
'With regard to the study of gymnosperms, the past is the key to the past' (Proposition to accompany the doctoral thesis 'On Callipteris Brongniart from the European Rotliegend Basins' by J. H. F. Kerp; translated from Dutch).
\end{abstract}

Johannes Henricus Franciscus (Hans) Kerp was born (1109-1954) and educated in Venlo in the southeastern part of The Netherlands, before going to Utrecht University to study Geology. He graduated cum laude in 1980, with Palaeobotany/Stratigraphy as his main specialization, and both Sedimentology and History of Science as additional subjects. Under the supervision of one of us (HV), he then started his renowned Ph.D. study on the classic Permian leaf fossil-genus Callipteris.

In 1986, when Hans defended his doctoral thesis, it was still the custom to add a list of one-sentence propositions to the thesis that could be debated at a scientific level. Propositions concerned not only the content of the thesis, but also different scientific or socially relevant topics covering other areas of the candidate's capabilities and interests. Hans's statement about the study of gymnosperms clearly belonged to the first category. In his successful search for the natural taxonomic affinity and ecology of the plant behind Callipteris, he had to rely exclusively on finding appropriate information from fossil plant assemblages and their palaeo-environmental context. Not surprisingly, he soon became widely recognized internationally as an outstanding expert on peltasperms and other gymnosperm groups which have no living relatives that could act as keys to the past. Throughout his further professional career, detailed study of late Palaeozoic and Triassic gymnosperms remained a major line of research that occupied Hans's attention. He

Henk Visscher

h.visscher@uu.nl

Johanna H. A. van Konijnenburg-van Cittert

j.h.a.vankonijnenburg@uu.nl

1 Laboratory of Palaeobotany and Palynology, PO Box 80.021, 3508 TA Utrecht, The Netherlands deserves tremendous credit for the way he brought cuticular analysis of gymnosperm leaves to perfection. Not the least of his accomplishments, by the way, is his use of (colour) photomicrography to illustrate the great contribution of epidermal structure in clarifying the taxonomy and ecology of extinct gymnosperms.

After completion of his Ph.D., Hans continued to work at the Laboratory of Palaeobotany and Palynology of Utrecht University. Apart from his involvement in palaeobotanical research and teaching programmes, he initiated organic petrological research with special emphasis on the botanical information contained in macerals. His activities in Utrecht were interrupted (1989-1990) when he went to the USA to work as a research associate with Professor Hermann Pfefferkorn at the University of Pennsylvania in Philadelphia. Meanwhile, he had married Wies van den Brink, who studied palynology in Utrecht. The couple are still happily wed and have two sons.

In 1991 Hans successfully applied for the vacant Professorship of Geology/Palaeobotany at the Westfälische Wilhelms-Universität in Münster, Germany. He faced the formidable task of succeeding the eminent palaeobotanist Professor Winfried Remy as leader of the Forschungsstelle für Paläobotanik, but he did this with great success. The comprehensive study of anatomically preserved plant tissue from the famous Rhynie Chert in Scotland, already initiated by Winfried Remy and his wife Renate in the 1970s, soon became a second major line of his research. Following Remy's death in 1995, Hans and his team continued to make startling new discoveries on the functional morphology, life history and ecology of early Devonian land plants from a unique, in situ permineralized ecosystem. Fruitful collaboration with Professor Thomas (Tom) Taylor of the University of Kansas led to the detection of unequivocal evidence of diverse plant-fungal interactions that may well be compared to those in modern ecosystems.

Of course, Hans's research interests in Münster did not remain restricted to deep-time gymnosperm floras and the Rhynie Chert biotope. A glance through his long list of authored and co-authored publications reveals, for example, his continuous involvement in a wide variety of projects, 


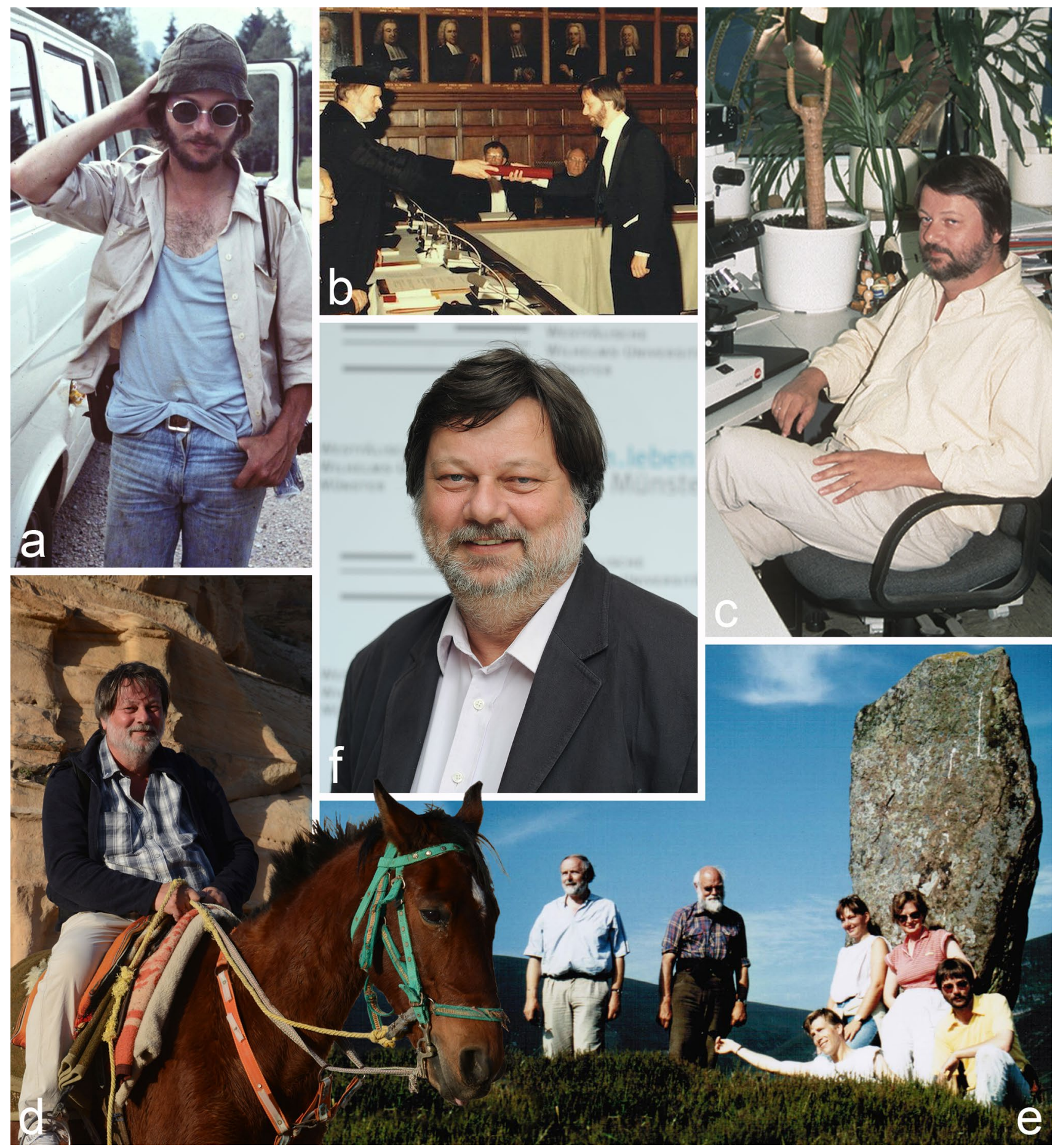

Fig. 1 Snapshots of a palaeobotanist's career. a Young Hans during a field trip to the Dolomites, Italy (August 1980). b Hans receives his $\mathrm{Ph} . \mathrm{D}$. certificate at the Senate Hall of Utrecht University (December 03, 1986). c Pondering fossil plants: Hans in his former office at the Forschungsstelle für Paläobotanik, Hindenburgplatz 55, in Münster (July 07, 2002). d Hans on horseback, exploring the ancient city of Petra (Jordan; March 04, 2019). e Hans collecting Late Jurassic plants at the coast of Sutherland, together with Henk Visscher, Johan van der Burgh, Johanna H. A. van Konijnenburg-van Cittert and two master students (Scotland, UK, July 1990). f From 2002 to 2016, Hans served as the dean of Geosciences of the University of Münster. Image credits $=$ (a) Henk Brinkhuis, (d) Benjamin Bomfleur, (f) $\odot$ CWWU/Peter Grewer, with permission of the Westfälische Wilhelms-Universität Münster, (b, c, e) photographer unknown 
in which analysis of plant megafossils and/or microfossils could contribute to solving diverse stratigraphic, phytogeographic or palaeo-environmental problems. What much of his work has in common is his critical re-appraisal of earlier data and concepts while striving to set new information in an historical context. Perhaps this special zeal for history is best reflected in his analysis of the fierce debates that erupted in the early 1980s after Luis Alvarez suggested that an asteroid had struck the earth at the time of the Cretaceous-Tertiary transition. In another of his one-sentence 'propositions', he dryly concluded: 'The precision with which people are now trying to set the Cretaceous-Tertiary boundary is beginning to resemble the precision with which they tried a few centuries ago to determine the time of the Biblical Flood'.

Being widely respected for his professionalism, over the course of his career Hans was regularly invited to hold organizational and editorial positions related to palaeobotanical research. Probably the most memorable of these was his appointment to editor-in-chief of the Review of Palaeobotany and Palynology. Until 2018 he had the final responsibility for the quality of the palaeobotanical content of the journal. Because of the vital role of first-class illustrations of plant fossils, he was particularly committed to improving the quality of the journal's photo plates, a rewarding but often frustrating task.

Having followed his achievements throughout his study and his professional career (Fig. 1), the two of us can confidently claim that Hans has developed exemplary insight in both biological and earth-scientific aspects of palaeobotany. We believe that he holds a place among the most talented palaeobotanists of his generation, and that his many students can consider themselves fortunate to have had him as a teacher and supervisor. It is gratifying to see that former Ph.D. students of Hans took the initiative of editing this Festschrift on the occasion of his 65th birthday. The Festschrift includes 14 research papers from students and colleagues of Hans, covering a wide range of topics that relate to his many areas of interest and expertise. 